\title{
The effect of temperature on hatch and activity of second-stage juveniles of the root-knot nematode, Meloidogyne minor, an emerging pest in north-west Europe
}

\author{
Karen S. Morris ${ }^{1,2, *}$, Finbarr G. Horgan ${ }^{3, * *}$, Martin J. Downes ${ }^{1}$ and Christine T. GRIFFIN ${ }^{1}$ \\ ${ }^{1}$ Department of Biology, National University of Ireland, Maynooth, Ireland \\ ${ }^{2}$ Teagasc, Kinsealy Research Station, Co. Dublin, Ireland \\ ${ }^{3}$ Teagasc, Oakpark Research Centre, Co. Carlow, Ireland
}

Received: 31 January 2011; revised: 29 March 2011 Accepted for publication: 2 April 2011; available online: 3 June 2011

\begin{abstract}
Summary - Meloidogyne minor is a serious threat to turfgrass in north-west Europe, and has a broad host range that includes other economically important plants. The species was described only recently and little is known about its biology. This study examines the effect of temperature on hatch and motility of second-stage juveniles (J2), and records hatching from egg masses collected from golf greens in different seasons. Eggs were present throughout the year and a high percentage hatch (46-88\%) was recorded when they were incubated at $20^{\circ} \mathrm{C}$. When egg masses were incubated at constant temperatures, $\mathrm{J} 2$ hatched between 15 and $25^{\circ} \mathrm{C}$, with limited hatch $(<1 \%)$ at 10 and $30^{\circ} \mathrm{C}$. The percentage hatch was lower at $15^{\circ} \mathrm{C}(43 \%)$ than at $20-25^{\circ} \mathrm{C}(63-76 \%)$. $\mathrm{J} 2$ hatched fastest at $23^{\circ} \mathrm{C}$, with an average duration to hatching of 7 days compared to 17 days at $15^{\circ} \mathrm{C}$. The range of temperatures at which $\mathrm{J} 2$ was active was broader than that at which they hatched. $\mathrm{J} 2$ were active from $4-30^{\circ} \mathrm{C}$, with greatest activity between 15 and $25^{\circ} \mathrm{C}$. The addition of grass root extract temporarily increased $\mathrm{J} 2$ activity at $10-20^{\circ} \mathrm{C}$, but not at lower temperatures.
\end{abstract}

Keywords - Agrostis stolonifera, creeping bentgrass, diapause, egg mass, golf green, stimulation, turfgrass.

Since 1997, golf greens in the United Kingdom and Ireland have displayed unusual yellow patches caused by a previously unidentified root-knot nematode (Entwistle, 2003). In 2004, the nematode was described as a new species, Meloidogyne minor (Karssen et al., 2004). This species favours sandy soils such as those at golf greens constructed according to United States Golf Association (USGA) guidelines. Meloidogyne minor has also been recorded in coastal dunes, pastures and sports grounds (Karssen et al., 2004; Turner \& Fleming, 2005; Lammers et al., 2006). In 2000, an outbreak of M. minor was recorded on potatoes in The Netherlands; the species has a wide host range that includes tomato and barley (Lammers et al., 2006). Prediction of the risk posed by the species, currently or in the context of future climate change, is hampered by the scarcity of fundamental knowledge of its biology, including its response to ambient temperatures.
Temperature influences all aspects of nematode life cycles and behaviour, including hatching, motility, invasion and development (Wallace, 1963; Davide \& Triantaphyllou, 1968; Bird, 1972; Evans \& Perry, 2009). There have been many studies showing the effects of temperature on Meloidogyne embryogenesis and hatch (Wallace, 1971; Ogunfowora \& Evans, 1977; Vrain \& Barker, 1978; Goodell \& Ferris, 1989; Ploeg \& Maris, 1999; Tzortzakakis \& Trudgill, 2005). Meloidogyne species vary in the temperature range over which hatching occurs; the optimal temperature for hatching is generally indicative of the geographic region or seasonal preference of their plant hosts (Lee \& Atkinson, 1976). Eggs produced in autumn may play an important role in the winter survival of Meloidogyne species (Jeger et al., 1993; Starr, 1993). In some species, such as M. naasi (Franklin, 1965), there is an obligate diapause requiring a period of chilling before second-stage juveniles (J2) will hatch (Ogunofowura \& Evans, 1977). Motility of the J2 is important both for

\footnotetext{
${ }^{*}$ Corresponding author, e-mail: Karen.morris@nuim.ie

** Current address: International Rice Research Institute, DAPO Box 7777, Metro Manila, The Philippines
} 
hatching and for penetration into the host and is affected by temperature (Prot \& Van Gundy, 1981; Roberts, 1987; Jeffers \& Roberts, 1993; Ploeg \& Maris, 1999).

In this study, we investigate the effects of constant temperatures on hatching and $\mathrm{J} 2$ motility of $M$. minor. We also assess the numbers and hatch rate of $M$. minor in egg masses collected throughout the year from a golf green sown with creeping bentgrass (Agrostis stolonifera var. stolonifera L.).

\section{Materials and methods}

\section{HATCHING OF J2 FROM EGG MASSES COLLECTED AT DIFFERENT TIMES OF THE YEAR}

Soil was collected using a soil corer $(1.9 \mathrm{~cm}$ diam.) to a depth of $10 \mathrm{~cm}$ on eight occasions over a 3-year period (Table 1). The soil was from infected patches on golf nursery greens in County Kildare, east Ireland, constructed to USGA guidelines and sown with A. stolonifera. Prior examination of infected greens, with nematode identification based on morphology, indicated that the dominant rootknot nematode present was M. minor, with M. naasi as an occasional minor component. Routine inspection of $\mathrm{J} 2$ in our trials did not reveal any $M$. naasi. Roots were gently rinsed with tap water to remove adhering soil. Egg masses with up to 2-3 $\mathrm{mm}$ of root on either side were placed in small hatching chambers and incubated at $20^{\circ} \mathrm{C}$. The hatching chambers, based on Southey (1986), consisted of plastic cylinders $15 \mathrm{~mm}$ high $\times 10 \mathrm{~mm}$ diam. with $20 \mu \mathrm{m}$ (pore size) mesh at the bottom, through which M. minor
J2 could freely migrate. Each cylinder was suspended in a well of a 24-well flat-bottom tissue culture plate containing $500 \mu \mathrm{l}$ tap water so that the mesh was wet but the knots/egg masses were not submerged. The water containing the migrated $\mathrm{J} 2$ was collected and replaced every 2-3 days and the number of $\mathrm{J} 2$ was recorded. When hatching had ceased ( $c a$ 60 days) the egg masses were dissected and the remaining eggs were examined and counted with the aid of a dissecting microscope ( $\times 40$ magnification). There were at least three replicate hatching chambers for each collection date, with four egg masses per chamber (2-7 in October 2003 and 1-5 in December 2003).

\section{THE EFFECT OF TEMPERATURE ON HATCHING}

Egg masses were incubated at each of ten temperatures: $4,6,8,10,15,20,23,25,30$ and $36^{\circ} \mathrm{C}$ for up to 63 days in small hatching chambers as described above. Two experiments were conducted, using egg masses collected from A. stolonifera on 25 February and 24 March 2004, respectively. There were three replicate hatching chambers per temperature treatment in the first experiment and six in the second. Each hatching chamber contained four egg masses. There were fewer eggs/egg mass in the first (mean $34.4 \pm 4.75$ ) than in the second experiment (mean 64.2 \pm 6.21$)\left(F_{1,88}=17.96, P<\right.$ $0.001)$, but there was no difference in numbers of eggs assigned to the various temperature treatments within an experiment (February $\left(F_{9,20}=0.62, P=0.763\right)$, March $\left.\left(F_{9,50}=1.09, P=0.384\right)\right)$.

Table 1. Percentage hatch, number of hatched J2 per egg mass and total number of eggs per egg mass for egg masses of Meloidogyne minor collected at different times of the year and incubated at $20^{\circ} \mathrm{C}$.

\begin{tabular}{lccc}
\hline Date & $\begin{array}{c}\text { Number hatched J2 } \\
\text { per egg mass } \\
(\text { mean } \pm \text { SE) }\end{array}$ & $\begin{array}{c}\text { Total number of eggs } \\
\text { per egg mass } \\
(\text { mean } \pm \text { SE) }\end{array}$ & $\begin{array}{c}\text { Percentage hatch } \\
(\text { mean } \pm \text { SE) }\end{array}$ \\
\hline Oct 2003 & $58.1 \pm 9.37 \mathrm{~A}$ & $117.1 \pm 8.08 \mathrm{AB}$ & $49.0 \pm 4.99 \mathrm{AB}$ \\
Dec 2003 & $40.0 \pm 10.37 \mathrm{~A}$ & $59.1 \pm 15.67 \mathrm{BC}$ & $69.9 \pm 7.39 \mathrm{AB}$ \\
Feb 2004 & $45.0 \pm 21.36 \mathrm{~A}$ & $56.3 \pm 24.55 \mathrm{BC}$ & $73.6 \pm 8.05 \mathrm{AB}$ \\
Mar 2004 & $18.2 \pm 4.90 \mathrm{~A}$ & $21.8 \pm 4.80 \mathrm{C}$ & $76.5 \pm 9.6 \mathrm{AB}$ \\
Aug 2005 & $29.9 \pm 10.39 \mathrm{~A}$ & $40.4 \pm 14.75 \mathrm{BC}$ & $72.4 \pm 9.26 \mathrm{AB}$ \\
Sept 2005 & $122.7 \pm 10.06 \mathrm{~B}$ & $139.4 \pm 11.7 \mathrm{~A}$ & $87.9 \pm 1.08 \mathrm{~A}$ \\
Apr 2006 & $22.0 \pm 1.55 \mathrm{~A}$ & $30.4 \pm 2.24 \mathrm{C}$ & $73.6 \pm 3.22 \mathrm{AB}$ \\
May 2006 & $33.1 \pm 1.69 \mathrm{~A}$ & $73.6 \pm 13.02 \mathrm{BC}$ & $46.7 \pm 5.49 \mathrm{~B}$ \\
& $F_{7,52}=12.94, P<0.001$ & $F_{7,52}=9.23, P<0.001$ & $F_{7,52}=2.54, P=0.025$ \\
\hline
\end{tabular}

Numbers within a column accompanied by the same letter are not significantly different, Tukey's test, $\alpha=0.05$.

${ }^{1}$ Total eggs $=$ number hatched $\mathbf{J} 2$ + eggs remaining when hatching ceased. 


\section{THE EFFECT OF TEMPERATURE AND STIMULATION ON J2 MOTILITY}

The $\mathrm{J} 2$ used in this experiment were extracted from egg masses (from A. stolonifera collected in September 2006) using evaporation dishes as collection trays (Southey, 1986) and were $\leqslant 1$-day-old (i.e., they had been in the collecting tray for less than a day). The motility of $\mathrm{J} 2$ was recorded at a range of temperatures $\left(4-30^{\circ} \mathrm{C}\right)$ in wells $(0.7 \mathrm{~cm}$ diam. $\times 1 \mathrm{~cm}$ deep $)$ of a $1 \times 12$-well Microstrip (Flow Laboratories, Helsinki, Finland). Each well contained $50 \mu \mathrm{l}$ of sterile tap water. The J2 were transferred from the evaporating dish to a well using a metal wire pick. Each well contained one J2, and only one J2 was transferred and observed at a time. The Microstrip was placed in a shallow water bath with a glass base to facilitate viewing. The temperature of the water bath was adjusted by circulating coolant through a loop of copper tubing from a recirculating water bath (Grant Instruments, Cambridge, UK). The temperature of the water in a well adjacent to the experimental well was monitored throughout the experiment. The J2 were observed using a dissecting microscope at $\times 40$ magnification. The microscope was fitted with a cold (fibre optic) light source. The $\mathrm{J} 2$ were allowed 3 min to adapt before their movement was recorded. The rate of $\mathrm{J} 2$ movement was measured by assessing head movement i.e., starting with the nematode's head in line with the rest of the body, a head movement occurred when the head moved $>90^{\circ}$ angle to the body in any direction. For example, from the centre to the left is one head movement, and left to centre is one head movement.

There were two experiments. In the first, $\mathrm{J} 2$ movement was recorded at $4,6,8,10,12,15,20,23,25$ and $30^{\circ} \mathrm{C}$. There were ten $\mathrm{J} 2$ per temperature treatment and each J2 was used once only. Each nematode was observed for $5 \mathrm{~min}$. A second experiment was done to see if $\mathrm{J} 2$ that were inactive at lower temperatures were capable of activity when stimulated. Grass root extract, made from fresh creeping bentgrass roots, was used to stimulate activity. The roots $(5 \mathrm{~g})$ were ground in $2 \mathrm{ml}$ tap water with a mortar and pestle. A pinch of sand was added during grinding to aid the breakdown of the cell walls. The sand and large debris particles were allowed to settle before the supernatant was used. Six temperatures (4, $6,10,12,15,20^{\circ} \mathrm{C}$ ) were used in the experiment with $15 \mathrm{~J} 2$ per temperature. After a 3 min acclimation period each nematode's movement was recorded for $2.5 \mathrm{~min}$ at the target temperature. Grass root extract $(10 \mu \mathrm{l})$ was slowly added to the well. The behaviour was recorded immediately for another $2.5 \mathrm{~min}$. This was followed by an immediate third recording of $2.5 \mathrm{~min}$.

\section{DATA ANALYSIS}

Minitab 14.0 was used for all statistical analysis. Data were checked for normality using the Anderson Darling test. Treatments were compared using General Linear Model ANOVA. Two similar experiments were carried out for the effect of temperature on hatching. A General linear model ANOVA showed that temperature had a highly significant effect on the percentage hatch but experiment did not, and there was no interaction between the two factors. The same was found for the mean time to hatch. Therefore, the data for the two experiments were pooled for subsequent analysis. Where differences were detected, means were separated using Tukey's test at $\alpha=0.05$.

\section{Results}

\section{HATCHING OF J2 FROM EGG MASSES COLLECTED AT DIFFERENT TIMES OF THE YEAR}

Eggs collected from the field at all times of the year hatched at $20^{\circ} \mathrm{C}$. The number of eggs and percentage hatch varied between sampling dates (Table 1). The percentage hatch ranged from $47 \%$ (May 2006) to $88 \%$ (September 2005), with a significant difference between the highest and lowest values. In October 2003 and May 2006 the percentage hatch was less than $50 \%$ but at all other times it was $70 \%$ or higher.

The average number of eggs/egg mass varied from 22 to 139 (Table 1). The highest number, in September 2005, was significantly different from that of every other month except October 2003. The number of $\mathbf{J} 2$ that hatched at $20^{\circ} \mathrm{C}$ also varied between collection dates. There were significantly more J2 in September 2005 than in any other month (Table 1). In order to investigate seasonal trends, the data for total numbers of eggs and numbers of hatched J2 were plotted against month (assuming that seasonal factors determine reproductive output), irrespective of which year they were sampled (Fig. 1). This showed evidence of two peaks for total eggs, one in May and a larger one in September when the number of hatched J2 also peaked. Pearson Correlation failed to detect any significant relationship between percentage hatch and number of eggs/egg mass $(P=0.649, R=0.06)$. While the viability of unhatched eggs was not rigorously 


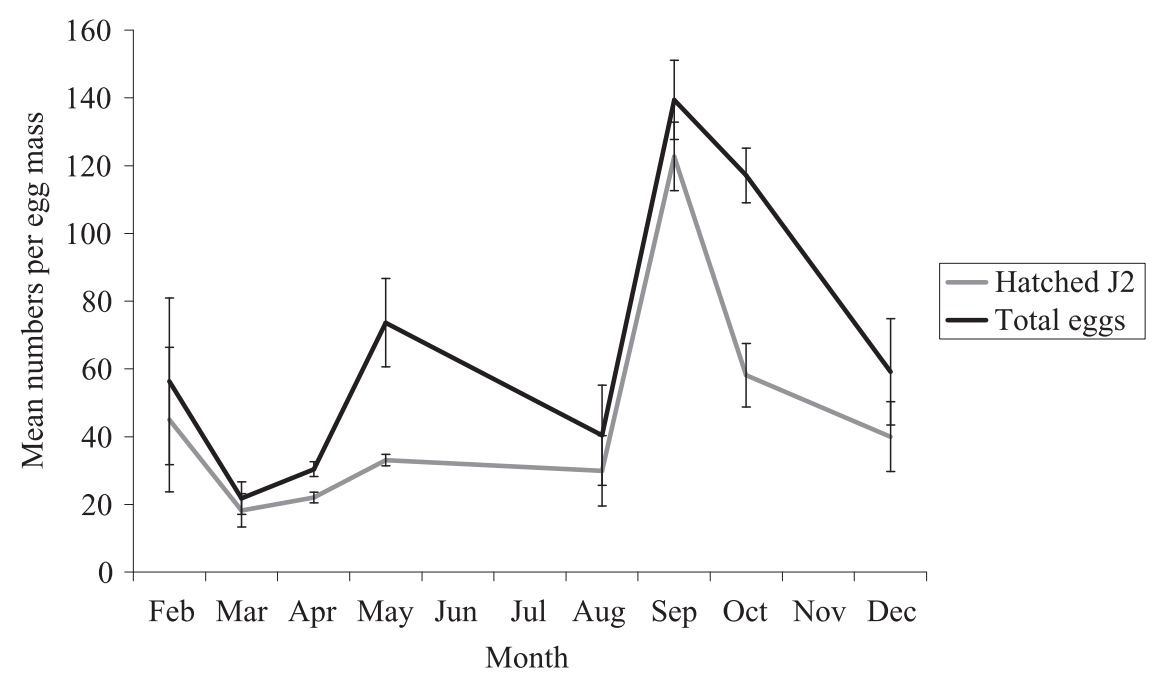

Fig. 1. The total number (mean $\pm S E$ ) of Meloidogyne minor eggs per egg mass and number (mean $\pm S E$ ) of hatched second juveniles (J2) per egg mass (hatched at $20^{\circ} \mathrm{C}$ ). Total eggs = number of $\mathrm{J} 2+$ eggs remaining once hatching ceased (empty eggshells were not counted). Months are displayed in order as in calendar year, not in order of collection.

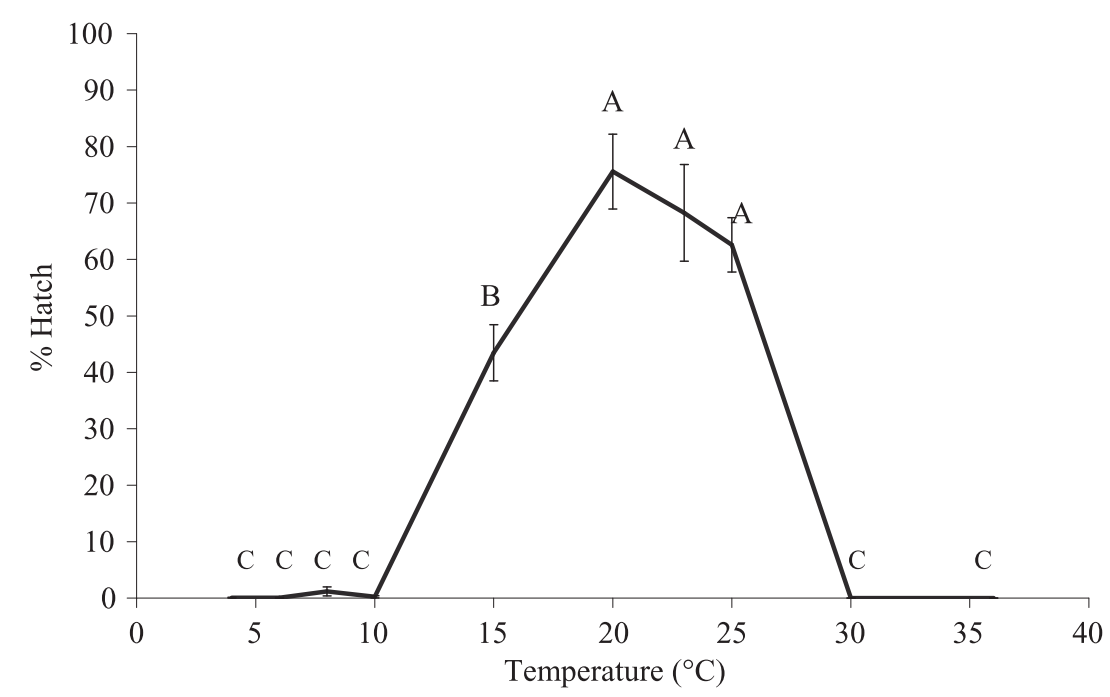

Fig. 2. Percentage hatch (mean $\pm S E$ ) of Meloidogyne minor after incubation for up to 63 days at various constant temperatures $(N=9)$. Points accompanied by the same letter are not significantly different $\left(\mathrm{F}_{9,71}=54.37, \mathrm{P}<0.001 ;\right.$ Tukey's test, $\left.\alpha=0.05\right)$.

assessed, most of them appeared to be degenerating when examined microscopically.

\section{THE EFFECT OF TEMPERATURE ON HATCHING}

The highest percentage hatch $(76 \%)$ was at $20^{\circ} \mathrm{C}$, but this did not differ significantly from that at 23 or $25^{\circ} \mathrm{C}$. At $15^{\circ} \mathrm{C}$, fewer than $50 \%$ of $\mathrm{J} 2$ hatched from eggs (Fig. 2). Very few $(<1 \%) \mathrm{J} 2$ hatched $\leqslant 10^{\circ} \mathrm{C}$ or $\geqslant 30^{\circ} \mathrm{C}$. Due to the low numbers it was not feasible to determine hatch time for these temperatures. The shortest mean time to hatch (approximately 7 days) was at $23^{\circ} \mathrm{C}$. This was different from $20^{\circ} \mathrm{C}$ but not $25^{\circ} \mathrm{C}$. Hatching took more than twice as long at $15^{\circ} \mathrm{C}$ as at $23^{\circ} \mathrm{C}$ (Fig. 3).

\section{EFFECT OF TEMPERATURE AND STIMULATION ON J2 MOTILITY}

$\mathrm{J} 2$ were active in water at all temperatures tested between 4 and $30^{\circ} \mathrm{C}$ (Fig. 4). Temperature affected motil- 


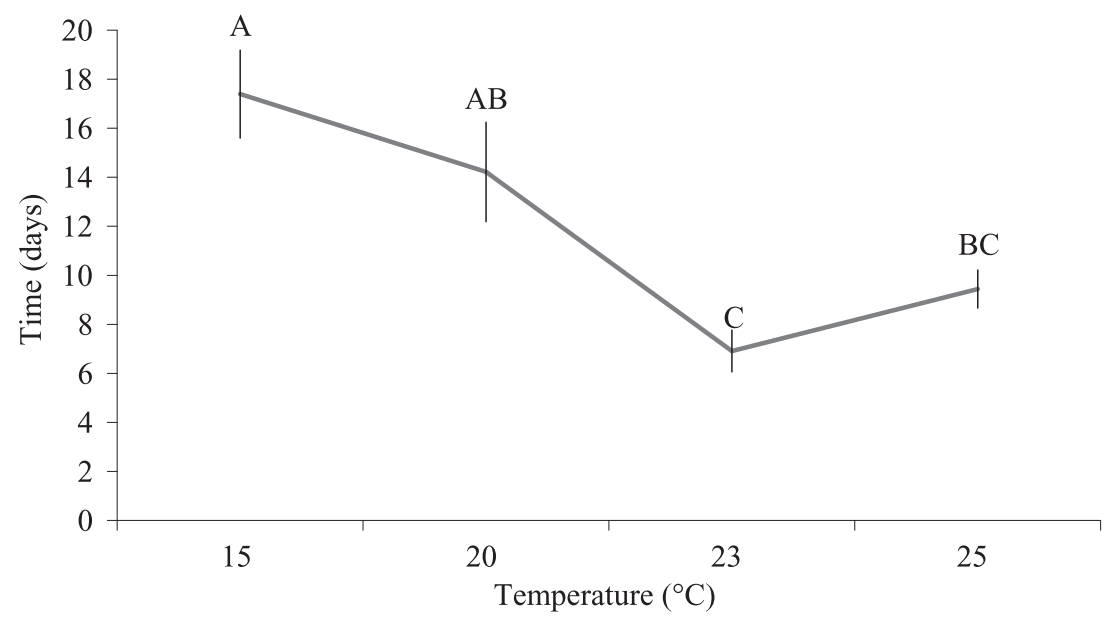

Fig. 3. Time to hatch (mean $\pm S E$ ) of Meloidogyne minor incubated at various constant temperatures $(N=9)$. Points accompanied by the same letter are not significantly different $\left(\mathrm{F}_{3,52}=10.23, \mathrm{P}<0.001\right.$; Tukey's test, $\left.\alpha=0.05\right)$.

ity $\left(F_{9,90}=34.16, P<0.001\right)$. All $\mathrm{J} 2$ were active at $10-30^{\circ} \mathrm{C}$, but the highest rate of activity (head movements $5 \mathrm{~min}^{-1}$ ) occurred between 15 and $25^{\circ} \mathrm{C}$. Activity levels at these temperatures were nearly identical (approximately 57 head movements $5 \mathrm{~min}^{-1}$ ) but decreased again at $30^{\circ} \mathrm{C}$ (Fig. 4). Below $10^{\circ} \mathrm{C}$, not all $\mathrm{J} 2$ were active and their movement was slow. In a second experiment, grass root extract was used to stimulate $\mathrm{J} 2$ activity at various temperatures $\left(4-20^{\circ} \mathrm{C}\right)$ with particular emphasis on the lower temperatures where $\mathrm{J} 2$ were relatively inactive in the first experiment. The $\mathrm{J} 2$ activity was recorded in three adjacent periods: immediately before and immediately after addition of the stimulus, and a third adjacent time slot immediately afterwards. A two-way ANOVA revealed that root extract $\left(F_{2,252}=41.4, P<0.001\right)$, temperature $\left(F_{5,252}=531.63, P<0.001\right)$ and their interaction $\left(F_{2,10}=12.15, P<0.001\right)$, had a significant effect on $\mathrm{J} 2$ movement. As in the previous experiment, there was very little activity at 4,6 and $8^{\circ} \mathrm{C}$. At these temperatures the root extract did not have an effect on activity (Fig. 5). The addition of the grass root extract did have an effect on the $\mathrm{J} 2$ at the higher temperatures $\left(10-20^{\circ} \mathrm{C}\right)$. There was an immediate increase in activity after the addition of the extract. This effect did not persist for the next 2.5-min observation period, except at $10^{\circ} \mathrm{C}$.

\section{Discussion}

Eggs were found in egg masses throughout the year, and a high percentage hatch was recorded when they were incubated at $20^{\circ} \mathrm{C}$. This indicates that if there is diapause then it is not present in a high proportion of the population, unlike M. naasi. Ogunfowora and Evans (1977) incubated field-collected M. naasi eggs at $20^{\circ} \mathrm{C}$ and found that there was a higher percentage hatch from eggs collected in November than in August. This can be explained as the requirement of a large proportion of $M$. naasi eggs within a population for a period of chilling before hatch, a form of diapause (Evans \& Perry, 2009). In our study, the low hatch (49\%) in October might be interpreted as eggs being in diapause but not having experienced a long enough cold period. However, similar low hatch $(47 \%)$ was also seen in May, so other factors must be involved, such as age of females, or condition of soil and/or plant (Huang \& Pereira, 1994; Gaur et al., 2000; Wesemael et al., 2006). The M. minor eggs remaining once hatch had ceased appeared to be degenerating, but we cannot be certain that there were no viable eggs amongst them. It is possible that addition of root diffusate may have increased hatch rates; while most species of Meloidogyne hatch in water, hatch rate of some species may be enhanced by host root extract, especially at certain times of the year (Wesemael et al., 2006).

This study shows that the minimum temperature for M. minor hatch is between 10 and $15^{\circ} \mathrm{C}$, and that hatch occurred from 15 to $25^{\circ} \mathrm{C}$. Although suboptimal, $15^{\circ} \mathrm{C}$ was still quite suitable for hatching of $M$. minor $\mathrm{J} 2$ : the percentage hatch was approximately $45 \%$ and the mean time to hatch did not differ from that at $20^{\circ} \mathrm{C}$. The shape of the curve (Fig. 3) suggests that $20^{\circ} \mathrm{C}$ is the optimum temperature for percentage hatch, though 

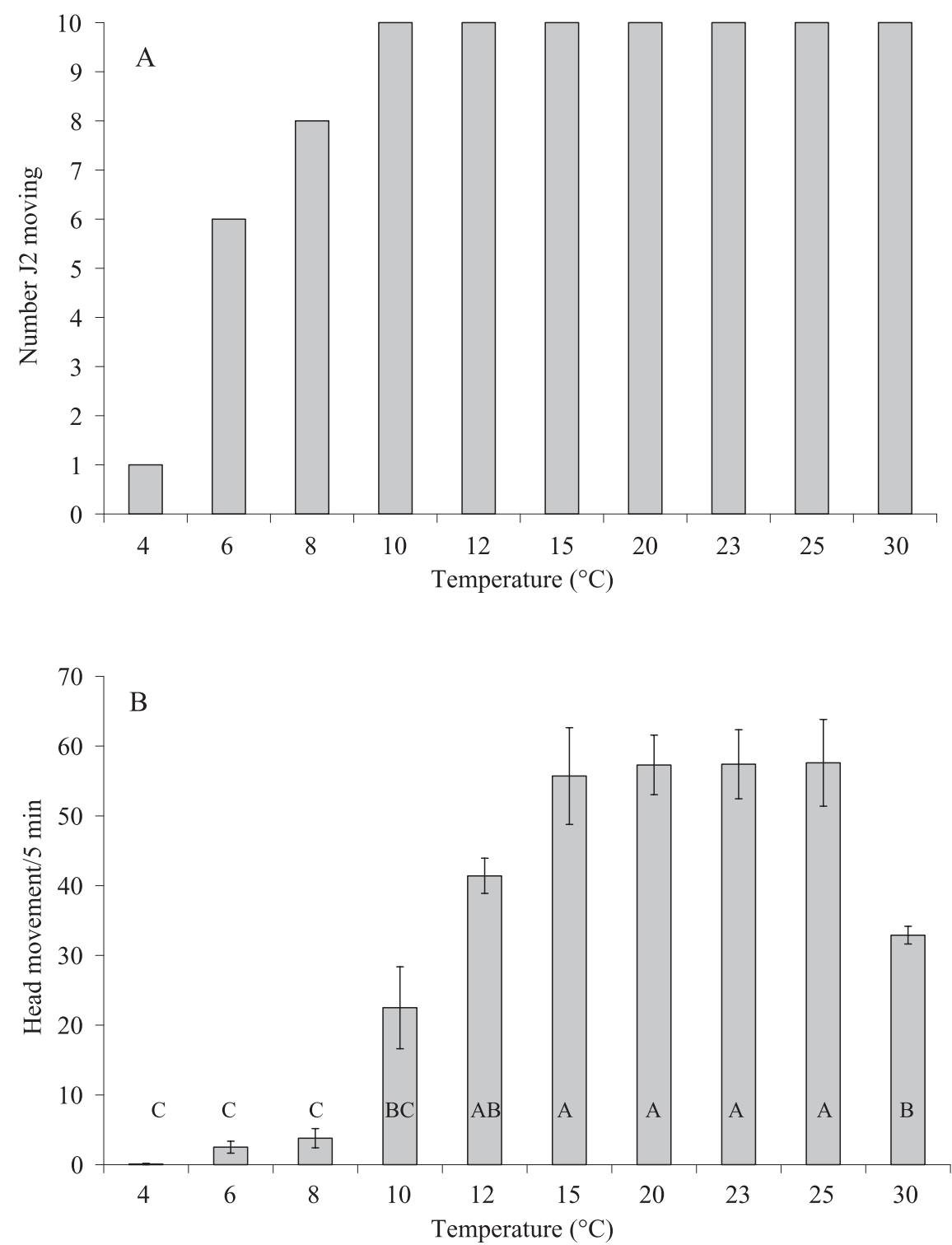

Fig. 4. Movement of second-stage juveniles (J2) of Meloidogyne minor at various constant temperatures $(N=10)$. A: Number of $J 2$ moving. B: Number (mean $\pm S E$ ) of head movements $5 \mathrm{~min}^{-1}$. Bars accompanied by the same letter are not significantly different $\left(\mathrm{F}_{9,90}=34.16, \mathrm{P}<0.001 ;\right.$ Tukey's test $\left.\alpha=0.05\right)$.

not significantly different from 23 and $25^{\circ} \mathrm{C}$. The shortest mean time to hatch ( $c$ a 7 days) occurred at $23^{\circ} \mathrm{C}$, which was significantly shorter than at $20^{\circ} \mathrm{C}$. So, combining the percentage hatch and time to hatch, it would appear that the optimum temperature for hatch is close to $23^{\circ} \mathrm{C}$, or more broadly between 20 and $25^{\circ} \mathrm{C}$. This is typical of cold-adapted species (including $M$. naasi and $M$. hapla) where the optimum temperature is between 15 and $25^{\circ} \mathrm{C}$, whereas $25-30^{\circ} \mathrm{C}$ appears optimal for warm climate species such as M. javanica (Bird \& Wallace, 1965; Wallace, 1971; Bird, 1972; Ogunfowora \& Evans, 1977). Nevertheless, the effective range for M. minor hatch in this study $\left(15-25^{\circ} \mathrm{C}\right)$ appears skewed towards lower temperatures compared with a Welsh population of M. naasi, where there was negligible hatch at $15^{\circ} \mathrm{C}$ but up to $10 \%$ hatch at $30^{\circ} \mathrm{C}$ (Ogunfowora \& Evans, 1977). 


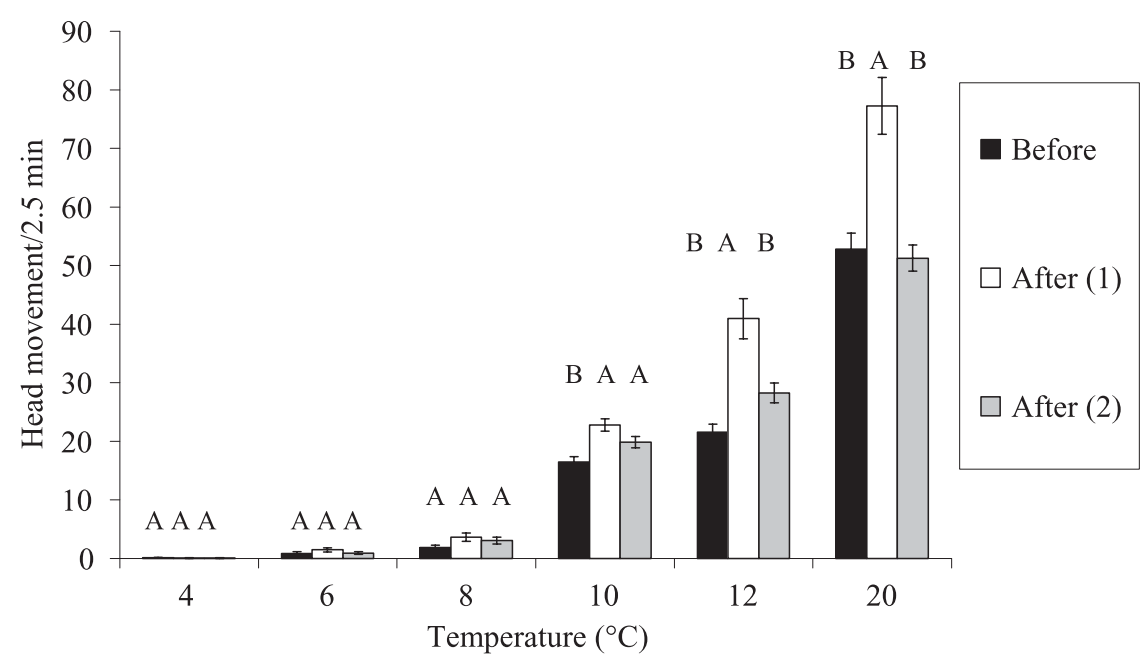

Fig. 5. Movement of second-stage juveniles (J2) of Meloidogyne minor (mean $\pm S E$ head movements $2.5 \mathrm{~min}^{-1}$ ) at various constant temperatures before and after application of grass root extract. After $(1)=$ from time of application of extract; After (2) $=$ from 2.5 min after application of extract $(N=15)$. Within a temperature, bars accompanied by the same letter are not significantly different (Tukey's test, $\alpha=0.05$ ).

We used egg masses collected in February and March as it is from these that the first $\mathrm{J} 2$ of the season will emerge (Morris, 2008), and soil temperatures are most likely to be limiting. It is possible that egg masses produced at different times of the year might respond differently to temperature (e.g., Ogunfowora \& Evans, 1977) but this was not examined here.

Meloidogyne $\mathrm{J} 2$ are sensitive to temperature as indicated through monitoring of J2 mobility (Robinson, 1994). This can also influence infectivity (Bergerson, 1959; Van Gundy et al., 1967; Roberts et al., 1981). Both nematode movement through soil and penetration into the plant require that the environmental temperature be above a certain threshold, otherwise nematode muscular activity is greatly reduced (Prot \& Van Gundy, 1981; Roberts et al., 1981). The present study indicates that M. minor $\mathrm{J} 2$ are capable of movement at all temperatures from 4 to $30^{\circ} \mathrm{C}$, but at varying rates. From 10 to $30^{\circ} \mathrm{C}$ all $\mathrm{J} 2$ moved $(100 \%)$ but they were most active between 15 and $25^{\circ} \mathrm{C}$. The temperature at which movement is inhibited varies among species and between strains from different geographical regions; for example, $M$. incognita movement was inhibited at $18^{\circ} \mathrm{C}$ (Prot \& Van Gundy, 1981), whilst $M$. hapla can penetrate alfalfa roots at $10^{\circ} \mathrm{C}$ (Griffin, 1969). In our study, all M. minor J2 were active at $10^{\circ} \mathrm{C}$, but moved at only half the rate seen in the optimal temperature range. Below $10^{\circ} \mathrm{C}$, the rate of activity was very low. This could be either because the $\mathrm{J} 2$ were un- able to move (e.g., the temperature was too low for neural or muscular activity) or because they responded to low temperature as a cue to become inactive in the absence of other stimuli for activity. If they were capable of activity, then we suggest that they should be activated by cues associated with their host plant (Perry, 1997). At $8^{\circ} \mathrm{C}$ and below, the addition of grass root extract had no significant effect on $\mathrm{J} 2$ activity confirming that the ability to move rather than the 'motivation' to move is severely reduced at these temperatures. At 10,12 and $20^{\circ} \mathrm{C}$ there was an increase in activity after the addition of the grass root extract. However, the effect of the stimulus was short lived. A rapid return to baseline activity following a period of increased activity provoked by stimulation is typical of the infective juveniles of parasitic nematodes (Croll, 1972) and presumably conserves energy.

In general, the optimum temperature for a root-knot nematode corresponds to that of the host plant (Luc et al., 2005). Agrostis stolonifera is a cool season turfgrass species that grows well in cool humid regions (Warnke, 2003) including Britain and Ireland (Sell \& Murrell, 1996) and is one of M. minor's natural hosts (Lammers et al., 2006). Most cool-season turfgrasses have optimal root growth at soil temperatures between 10 and $18^{\circ} \mathrm{C}$ (Landschoot, 2007). Pote et al. (2006) found root zone temperatures of $23^{\circ} \mathrm{C}$ or above were detrimental to root activities of creeping bentgrass. In the present study, the optimum temperature for $M$. minor hatch was $20-25^{\circ} \mathrm{C}$, 
and for $\mathrm{J} 2$ activity was $15-25^{\circ} \mathrm{C}$, somewhat higher than the preferred temperature for $A$. stolonifera root growth.

We show here that the minimum temperature for hatch of $M$. minor is between 10 and $15^{\circ} \mathrm{C}$, and this accords with field collections from turfgrass where J2 were absent in winter, and first recovered once soil temperature exceeded $10^{\circ} \mathrm{C}$ in March (Morris, 2008). As temperatures in the current geographic range of $M$. minor are expected to increase by $1.4-1.8^{\circ} \mathrm{C}$ by the 2050 s (Sweeney et al., 2008), we may expect an extended season for hatch of the species. It is unclear to what extent different Meloidogyne activities such as hatching, invasion, growth and embryogenesis have different thermal requirements. Bird and Wallace (1965) found that the optimal temperatures for growth and development of Meloidogyne spp., both in the egg and in the plant, were higher than the thermal optima for stages in the soil (i.e., J2 motility), but similar to each other, while Trudgill (1995) showed that embryogenesis and the whole life cycle of $M$. javanica had similar base temperatures. Assuming similar thermal responses of all life cycle activities, soil temperatures up to at least $25^{\circ} \mathrm{C}$ are likely to favour the species and exacerbate its pest status.

\section{Acknowledgements}

The work was funded by a Teagasc Walsh Fellowship. The authors thank Dr G. Karssen (Plant Protection Service, Wageningen, The Netherlands) for confirming the identification of $M$. minor.

\section{References}

BERGERSON, G.B. (1959). The influence of temperature on the survival of some species of the genus Meloidogyne in the absence of a host. Nematologica 4, 344-354.

BIRD, A.F. (1972). Influence of temperature on embryogenesis in Meloidogyne javanica. Journal of Nematology 4, 206-213.

Bird, A.F. \& Wallace, H.R. (1965). The influence of temperature on Meloidogyne hapla and M. javanica. Nematologica 11, 581-589.

CrOLl, N.A. (1972). Behavioural activities of nematodes. Helminthological Abstracts Series A 41, 359-377.

DAVIDE, R.G. \& TRIANTAPHYllou, A.C. (1968). Influence of environment on development and sex differentiation of root-knot nematodes. 3. Effect of foliar application of maleic hydrazide. Nematologica 14, 37-46.

EnTwistle, K. (2003). Root knot nematode infection of creeping bentgrass greens. Greenkeeper International, February 2003.
Evans, A.A.F. \& PERry, R.N. (2009). Survival mechanisms. In: Perry, R.N., Moens, M. \& Starr, J.L. (Eds). Root-knot nematodes. Wallingford, UK, CABI Publishing, pp. 201-222.

FrANKLIN, M.T. (1965). A root-knot nematode, Meloidogyne naasi n. sp., on field crops in England and Wales. Nematologica $11,79-88$.

GAUR, H.S., BEAnE, J. \& PERry, R.N. (2000). The influence of root diffusate, host age and water regimes on hatching of the root-knot nematode, Meloidogyne triticoryzae. Nematology 2, 191-199.

GOODELL, P.B. \& FERRIS, H. (1989). Influence of environmental factors on the hatch and survival of Meloidogyne incognita. Journal of Nematology 21, 328-334.

GRIFFIN, G.D. (1969). Attractiveness of resistant and susceptible alfalfa to stem and root-knot nematodes. Journal of $\mathrm{Ne}$ matology 1, 9. [Abstr.]

HuAng, S.P. \& PeREIRA, A.C. (1994). Influence of inoculum density, host, and low-temperature period on delayed hatch of Meloidogyne javanica eggs. Journal of Nematology 26, 7275.

JefFERS, D.P. \&. RoBerTs, P.A. (1993). Effect of planting date and host genotype on the root-knot nematode - Fusarium wilt disease complex of cotton. Phytopathology 83, 645-654.

Jeger, M.J., Starr, J.L. \& WiLson, K. (1993). Modelling winter survival dynamics of Meloidogyne spp. (Nematoda) eggs and juveniles with egg viability and population losses. Journal of Applied Ecology 30, 496-503.

Karssen, G., Bolk, R.J., VAN AELst, A.C., VAN DEN Beld, I., Kox, L.F.F., Korthals, G., Molendij, L., ZiJlstra, C., Van Hoof, R. \& Cook, R. (2004). Description of Meloidogyne minor n. sp. (Nematoda: Meloidogynidae), a root-knot nematode associated with yellow patch disease in golf courses. Nematology 6, 59-72.

Lammers, W., Karssen, G., Jellema, P., Baker, R., Hockland, S., Fleming, C. \& Turner, S. (2006). Meloidogyne minor: pest risk analysis. Available online at http:// www.fera.defra.gov.uk/plants/plantHealth/pestsDiseases/ documents/meloidogyneminor.pdf (accessed 9 November 2010).

LANDSCHOOT, P. (2007). The cool season turfgrasses: basic structures, growth and development. Available online at http://cropsoil.psu.edu/turf/extension/factsheets/pdfs/coolseason.pdf/view?searchterm=coolseason turfgrass (accessed 9 November 2010).

LeE, D.L. \& AtKinson, H.J. (1976). The physiology of nematodes, 2nd edition. London, UK, Macmillan Press, $215 \mathrm{pp}$.

LuC, M., SikorA, R.A. \& Bridge, J. (2005). Plant parasitic nematodes of tropical and subtropical agriculture, 2nd edition. Wallingford, UK, CABI Publishing, 877 pp.

Met EIREAnN (2008). [Online] The Irish meteorological service online. Available online at http://www.met.ie/ (accessed 9 November 2010). 
MorRIS, K.M. (2008). Demographics and biological control of the root-knot nematode Meloidogyne minor on creeping bentgrass (Agrostis stolonifera). Ph.D. Thesis, National University of Ireland Maynooth, Ireland.

Ogunfowora, A.O. \& Evans, A.A.F. (1977). Factors affecting hatch of eggs of Meloidogyne naasi, an example of diapause in a 2nd stage larva. Nematologica 23, 137-146.

PERRY, R.N. (1997). Plant signals in nematode hatching and attraction. In: Fenoll, C., Grundler, F.M.W. \& Ohl, S. (Eds). Cellular and molecular aspects of plant-nematode interactions. Dordrecht, The Netherlands, Kluwer, pp. 38-50.

Ploeg, A.T. \& MARIS, P.C. (1999). Effects of temperature on the duration of the life cycle of a Meloidogyne incognita population. Nematology 1, 389-393.

Pote, J., Wang, Z.L. \& Huang, B.R. (2006). Timing and temperature of physiological decline for creeping bentgrass. Journal of the American Society for Horticultural Science 131, 608-615.

PROT, J.C. \& VAN GUNDY, S.D. (1981). Influence of photoperiod and temperature on migrations of Meloidogyne juveniles. Journal of Nematology 13, 217-220.

ROBERTS, P.A. (1987). The influence of planting date of carrot on Meloidogyne incognita reproduction and injury to roots. Nematologica 33, 335-342.

Roberts, P.A., VAn Gundy, S.D. \& MCKinney, H.E. (1981). Effects of soil-temperature and planting date of wheat on Meloidogyne incognita reproduction, soil populations, and grain-yield. Journal of Nematology 13, 338-345.

Robinson, A. (1994). Movement of five nematode species through sand subjected to natural temperature gradient fluctuations. Journal of Nematology 26, 46-58.

Sell, P. \& MURRell, G. (1996). Flora of Great Britain and Ireland. Volume 5: Butomaceae-Orchidaceae. Cambridge, UK, Cambridge University Press, 408 pp.

SOUTHEY, J.F. (1986). Laboratory methods for work with plant and soil nematodes. London, UK, Her Majesty's Stationery Office, $202 \mathrm{pp}$.
STARR, J.L. (1993). Recovery and longevity of egg masses of Meloidogyne incognita during simulated winter survival. Journal of Nematology 25, 244-248.

Sweeney, J., Albanito, F., Brereton, A., Caffara, A., Charlton, R., Donnelly, A., Fealy, R., Fitzgerald, J., Holden, N., Jones, M. ET AL. (2008). Climate change: refining the impacts for Ireland. Johnstown Castle, Co. Wexford, Ireland, Environmental Protection Agency, 163 pp.

TRudGiLl, D.L. (1995). An assessment of the relevance of thermal time relationships to nematology. Fundamental and Applied Nematology 18, 407-417.

TURNER, S.J. \& Fleming, C.C. (2005). Meloidogyne minor: a threat to temperate crops? Communications in Agricultural and Applied Biological Sciences 70, 885-887.

TzOrTZAKaKis, E.A. \& TRUdgiLl, D.L. (2005). A comparative study of the thermal time requirements for embryogenesis in Meloidogyne javanica and M. incognita. Nematology 7, 313-315.

VAN GUNDY, S.D., BIRD, A.F. \& WALlaCE, H.R. (1967). Aging and starvation in larvae of Meloidogyne javanica and Tylenchulus semipenetrans. Phytopathology 57, 559-571.

VRAIN, T.C. \& BARKER, K.R. (1978). Influence of low temperature on development of Meloidogyne incognita and Meloidogyne hapla eggs in egg masses. Journal of Nematology 10, 311-313.

WALLACE, H.R. (1963). The biology of plant parasitic nematodes. London, UK, Edward Arnold, 280 pp.

WALLACE, H.R. (1971). Influence of temperature on embryonic development and hatch in Meloidogyne javanica. Nematologica 17, 179-189.

WARNKE, S.E. (2003). Creeping bentgrass (Agrostis stolonifera L.). In: Casler, M.D. \& Duncan, R.R. (Eds). Turfgrass biology, genetics, and breeding. Hoboken, NJ, USA, John Wiley \& Sons, pp. 175-185.

Wesemael, W.M.L., Perry, R.N. \& Moens, M. (2006). The influence of root diffusates and host age on hatching of the root-knot nematodes, Meloidogyne chitwoodi and M. fallax. Nematology 8, 895-902. 